\title{
Perayaan Tabuik dan Tabot: Jejak Ritual Keagamaan Islam Syi'ah di Pesisir Barat Sumatra
}

\author{
Asril \\ Institut Seni Indonesia (ISI) Padangpanjang \\ Jl. Bundo Kanduang No 35 Padangpanjang
}

\begin{abstract}
This paper discusses the origin of Tabuik and Tabot ceremonies in Sumatera which possess influence from religious ceremony of Syiah community in Persia (Iran). The aim of the research is to figure out the acculturation which has occurred between the Arabian (Middle East) and local cultures. The research uses analytic descriptive method through literature study. The result of the research shows that Tabuik and Tabot ceremonies are carried out as a ritual to commemorate the death of Husein in Syiah community which has become theological religious main ritual, and its spread to the west coast Sumatera (Pariaman and Bengkulu) has changed the theological value into cultural ritual, even in some cases it only becomes a cultural performance.
\end{abstract}

Keywords: Tabuik and Tabot ceremony, religious ritual

\begin{abstract}
ABSTRAK
Tulisan ini membahas tentang asal-usul perayaan Tabuik dan Tabot di Sumatera yang mendapat pengaruh dari ritual keagamaan kaum Syi'ah di Persia (Iran). Tujuan penelitian ini untuk mengetahui sejauh mana akulturasi yang terjadi antara pengaruh budaya jazirah Arab (Timur Tengah) tersebut dengan budaya lokal. Penelitian ini menggunakan metode deskriptif analitis melalui studi kepustakaan. Hasil penelitian menunjukkan bahwa perayaan Tabuik dan Tabot dilaksanakan sebagai ritual mengenang kematian Husain di kalangan penganut Islam Syi'ah yang menjadi ritual utama keagamaan yang bersifat teologis, dan penyebarannya ke pantai Barat Sumatra (Pariaman dan Bengkulu) mengalami perubahan nilai dari teologis menjadi bentuk ritual budaya, bahkan dalam beberapa kesempatan hanya menjadi pertunjukan budaya saja.
\end{abstract}

Kata kunci: upacara Tabuik danTabot, ritual keagamaan

\section{PENDAHULUAN}

Tradisi ritual berskala besar dan kolosal yang dimiliki masyarakat pantai bagian Barat Sumatra adalah upacara Tabuik dan upacara Tabot. Upacara Tabuik terdapat di kota Pariaman (Provinsi Sumatra Barat), sedangkan upacara Tabot terdapat di kota Bengkulu (Provinsi Bengkulu). Kedua ritual ini merupakan peninggalan budaya dari ritual utama keagamaan Islam Syi'ah. Ritual Tabuik dan Tabot berasal dari peristiwa perang Karbala di Irak antara Yazid dari Bani Umayyah dengan Husain Bin Ali cucu Nabi Muhammad saw. Peristiwa ini terjadi tahun 680-bertepatan dengan 10 Muharam tahun 61 Hijriyah (Brockelmann, 
1956: 76; Ansary, 2009: 128; Yatim, 2000: 45; Gibb dan Kamer, 1974: 142; Asril, 2002: 42). Dalam peperangan itu,Husain dan pasukannya mati terbunuh kecuali beberapa perempuan dan anak-anak (Ahmad, 1972: 178). Perang yang tidak seimbang ini sering pula disebut sebagai pembantaian terhadap Husain dan rombongannya. Husain bagi penganut Syi'ah dianggap Imam $^{1}$ ketiga setelah ayahnya Ali bin Abi Thalib, dan Hasan bin Ali kakaknya. Kematian Husain meninggalkan duka yang mendalam bagi penganut Syi'ah. Kebesaran nama dan penghormatan terhadapnya dilakukan oleh umat Islam Syi'ah di seluruh dunia, dan tak terkecuali juga dari Islam Sunni di berbagai kawasan Asia Tenggara, termasuk di berbagai tempat di Indonesia. Bentuk penghormatan itu di kawasan Timur Tengah diwujudkan dalam pertunjukan drama bergaya sufi yang menyajikan kronologi penderitaan yang dialami oleh $\mathrm{Hu}-$ sain. Sementara di tempat lain ditafsir pula berdasarkan kekuatan budaya lokalnya, seperti yang masih dapat kita jumpai di kawasan pantai Barat Sumatra.

Uniknya, bentuk upacara dan perayaannya di masing-masing daerah tidak semata-mata bertolak dari peristiwa perang Karbala. Akan tetapi, dilakukan 'pemitosan' sejarah perang Karbala dengan menafsirkan dan memaknai sendiri rasa simpati terhadap Husain sesuai dengan versi daerah masing-masing. Peristiwa Karbala bisa menjadi seperti legenda. Penafsiran ini berimbas pada bentuk upacara, artefak upacara (tabuik dan tabot), spirit upacara, dan pelaksanaan upacara. Misalnya, di Pariaman tabuik diwujudkan dalam bentuk artefak yang dibuat setinggi sekitar 10-12 meter. Sementara di Bengkulu tabot ditafsir dari mimpi seorang leluhur keturunan tabot di Karbala. Ia melihat bangunan istana raja berbentuk piramida. Mimpi itu kemudian diwujudkan dengan bentuk artefak seperti menara setinggi sekitar 4-8 meter, yang me- miliki unsur seperti piramida.

Seiring dengan perkembangan zaman, ritual keagamaan Syi'ah itu berubah menjadi pertunjukan budaya. Muatan teologis sebagaimana ritual awalnya sudah tidak ditemukan lagi. Perubahan cenderung terjadi dari ritual ke sekuler, ataupun berubah secara parsial.

\section{Pengertian Tabut}

Kata tabuik berasal dari tabut (bahasa Arab) yang berarti peti atau peti kayu (Assegaf, 2010:63; Zubaedi, 2008: 49). Tabut dengan arti peti merupakan pengertian umum. Namun kata tabut memiliki konteks tertentu yang sangat luar biasa yaitu dengan Nabi Musa a.s., ritual keagamaan Islam Syi'ah, dan tabut di Sumatra. Dalam Al-Quran surat Al-Baqarah ayat 248 disebutkan yang artinya: “. . . sesungguhnya tanda kerajaannya ialah datangnya tabut kepadamu, yang di dalamnya terdapat ketenangan dari Tuhanmu dan sisa peninggalan keluarga Musa dan keluarga Harun, yang dibawa oleh malaikat ...." (Departemen Agama, 2006: 40; Kementerian Agama RI, 2010: 40).

Tabut itu berisi kitab Taurat yang memuat, 'Sepuluh Perintah Tuhan' (Ten Commandements). Tabut ini dikenal juga dengan Tabut Perjanjian atau Ark of Covenant, yaitu perjanjian antara Tuhan dengan Bani Israil. Dalam Al-Kitab (Perjanjian Lama) yang dikutip oleh Madjid (2000: 53), disebutkan Sepuluh Perintah Tuhan itu yaitu:

“Mengakui Allah, Tuhan Yang Maha Esa sebagai satu-satunya Tuhan (tawhid); (2) Hanya menyembah kepada Allah saja; (3) Jangan menyembah patung (syirik); (4) Menyebut nama Allah dengan penuh hormat; (5) Menghormati hari Sabtu (Shabbat); (6) Tidak membunuh; (7) Tidak berzina; (8) Tidak mencuri; (9) Tidak membuat kesaksian palsu; (10) Jangan tamak terhadap milik orang lain".

Versi lain Sepuluh Perintah Tuhan 
dalam Al-Kitab Holy Bibel (Yulimarni, 2011: 24-25) yaitu:

\begin{abstract}
"Jangan ada padamu Allah lain di hadapan$\mathrm{Ku}$; (2) Jangan membuat patung menyerupai apapun yang ada di langit, di atas dan di bumi, di bawah atau yang ada di dalam air di bawah bumi; (3) Jangan menyebut nama tuhan, Allahmu dengan sembarangan, sebab tuhan akan memandang bersalah orang yang menyebut nama-Nya dengan sembarangan; (4) Kuduskanlah hari sabat (hari sabtu); (5) Hormati ayahmu dan ibumu; (6) Jangan membunuh; (7) Jangan berzina; (8) Jangan mencuri; (9) Jangan mengucapkan saksi dusta tentang sesamamu; (10) Jangan mengingini rumah sesamamu, artinya, jangan menginginkan istrinya atau hambanya laki-laki, atau hambanya perempuan, atau lembunya atau keledainya atau apapun yang dipunyai sesamamu".
\end{abstract}

Tabut dalam kaitannya dengan ritual keagamaan Islam Syi'ah adalah peti mati (coffin) yang mempresentasikan kembali peti jenazah Husain (Grunebaum, 1951: 89). Perayaan kembali tentang kematian Husain pada 1-10 Muharam salah satu penanda yang terpenting adalah dengan mengusung tabut, yaitu berupa artefak dalam berbagai versi bentuk. Kata tabut dalam kaitan ini, menurut Esposito lebih banyak dikenal di India bagian selatan terutama di Dekkan dan Lucknow (Hasan, 1992: 3). Sementara di Indonesia pengucapan kata tabut, terjadi perubahan pelafalan menurut dialek masing-masing daerah, dari tabut menjadi tabuik (bahasa Minangkabau) di Sumatra Barat dan tabot di Bengkulu.

Jadi, tabut yang berisi Sepuluh Perintah Tuhan dengan tabuik, dan tabot, belum tentu memiliki kaitan sama sekali, karena ia terjadi pada kurun waktu yang berbeda, dalam konteks yang berbeda, dan dengan tujuan yang berbeda.

\section{Sekilas Sejarah Tabuik dan Tabot}

Masuknya tabuik ke Pariaman dari berbagai sumber diperoleh dalam versi yang berbeda. Konon menurut cerita yang berkembang di Pariaman, tabuik Pariaman berasal dari Bengkulu yang dibawa oleh orang Cipai (Sipahi). Mereka itu adalah Mak Sikajauna atau Tauna untuk tabuik subarang, dan Mak Labuah untuk tabuik pasa. Mereka berdua inilah yang melakukan upacara Tabuik dengan melibatkan masyarakat setempat. Mak Labuah bergabung dengan keluarga suku Mandailiang di daerah Kampung Perak (Pasar Pariaman), sedangkan Mak Sikajauna bergabung dengan suku Tanjung di daerah Kampung Jawa yang disebut dengan daerah subarang (V Koto Air Pampan).

Menurut versi ini sejak semula tabuik sudah ada dua di Pariaman (pasa dan subarang). Kemudian tabuik berkembang ke beberapa kampung atau korong, yaitu ke Karan Aur, Pauh, Jati, Cimparuh, Bato, dan Sungai Rotan. Akan tetapi, tabuik-tabuik baru itu bergabung ke tabuik pasa dan ke tabuik subarang. Kelompok tabuik pasa terdiri dari tabuik karan aur, tabuik cimparuh, dan tabuikbato, sedangkan anggota tabuik subarang terdiri dari tabuik sungai rotan, tabuik jati, dan tabuik pauah.

Kartomi (1986: 142) menyebutkan, bahwa orang pertama yang membawa tradisi ritual tabut dari India ke Bengkulu adalah seorang pemuka Islam yang bernama Imam Senggono dengan sebutan lain Syeikh Burhanuddin. Kemudian pemuka agama lainnya bernama Kadar Ali membawa tabut ke Pariaman. Snouck Hurgronje memperkirakan tabut berasal dari India dan masuk ke Sumatra diperkirakan pada abad XIV, diduga karena hikayat Ali Hanafiyah yang menceritakan tentang kematian $\mathrm{Hu}-$ sain, sudah diterjemahkan ke dalam bahasa Melayu pada masa itu. Ph.S. van Ronkel memperkirakan tabut masuk ke Sumatra pada akhir abad XVII, ketika Inggris membawa pasukan Sepoy India (orang Sipahi atau Cipai) yang berusaha menguasai pantai barat Sumatra, dan membantu menduduki benteng Marlborough di Bengkulu 
(Ronkel, 1914: 334-335; Kartomi, 1986: 144145). Sementara Azyumardi Azra (2000: 21) mencatat bahwa tabut masuk ke pantai barat Sumatra dalam kurun waktu antara tahun 1750-1825.

Andoni (2010: 116) menguatkan pendapat Azra, bahwa kedatangan tradisi tabuik pertama kali dibawa oleh tentara Sipahi (tentara Inggris dari etnik Sipahi India) pada tahun 1825, ketika Inggris menguasai pesisir barat Sumatra. Ia menjelaskan pula bahwa, sebelum kedatangan tentara Sipahi ke Sumatra (termasuk ke Pariaman), tarekat Syattariyah sudah disusupi oleh Syi'ah. Akan tetapi, tidak ada catatan bagaimana bentuk perayaan memperingati kematian Husain sebelum kedatangan tentara Sipahi.

Hamidy (1991/1992: 61) menyebutkan bahwa, upacara tabot dibawa ke Bengkulu oleh orang Sipahi yang bekerja membangun benteng Marlborough. Mereka berasal dari Madras India. Upacara ini kemudian diwariskan kepada keturunan mereka termasuk keturunan mereka hasil asimilasi dengan warga setempat. Kemudian dalam artikel Zubaedi (2008:49-50) dijelaskan bahwa, tabot masuk ke Bengkulu diperkirakan pada tahun 1685 yang dibawa oleh orangorang India yang menjadi tentara Inggris. Zubaedi juga mencatat, bahwa upacara berkabung dari penganut Syi'ah itu sudah ada sejak pembangunan benteng Marlborough tahun 1718-1719, dibawa oleh para tukang yang didatangkan Inggris dari Madras dan Bengali India bagian selatan. Adapun data yang berbeda lagi dikutip oleh Zubaedi (2008:52) dari Syiafril (tokoh tabot Bengkulu) mengatakan tabot dibawa ke Bengkulu oleh orang India pada tahun 1336.

Tampaknya, masuknya tabuik dan tabot ke Pariaman dan Bengkulu masih diperlukan penelitian kesejarahan yang mendalam untuk menjawabnya.

\section{Interpretasi Masyarakat}

Kendatipun perang Karbala adalah peristiwa sejarah kelam umat Islam di masa lalu, tetapi masyarakat Pariaman dan Bengkulu memandang peristiwa itu dengan persepsi yang berbeda. Peristiwa sejarah itu mereka tafsir dengan cara yang berbeda, yaitu dengan menciptakan mitos sendiri. Mitos itulah yang kemudian menjadi ilham dalam mewujudkan bentuk fisik tabuik dan tabot serta pelaksanaannya. Dengan pemitosan yang berbeda itu, maka terjadi pula perbedaan yang signifikan dari aspek bentuk upacara, struktur atau kronologi upacara, pelaksanaannya, dan spirit yang dimunculkannya.

Adapun mitos tabuik Pariaman dilukiskan oleh Nasrul Syam, tuo tabuik (tokoh Tabuik Pariaman) sebagai berikut.

\footnotetext{
“Setelah Husain terbunuh dengan kondisi tubuh dicincang oleh pasukan Yazid bin Muawiyah, tiba-tiba datanglah sebuah arakarakan dari langit yang terdiri dari para malaikat dan buraq, dengan membawa ornamen dan wewangian dari surga. Setelah arak-arakan itu mendarat di lokasi Husain terbunuh, para malaikat memasukkan bagian tubuh Husain ke dalam peti yang ada di punggung buraq, dan selanjutnya arak-arakan itu lepas landas menuju langit. Dalam perjalanan menuju langit, para malaikat mencium adanya bau manusia dalam rombongan tersebut, rupanya mereka prajurit Husain yang selamat yang berasal dari Cipahi (Keling) bergantung pada arak-arakan itu, dan ia memohon kepada malaikat agar ikut bersama jenazah Husain, tetapi malaikat tidak mengizinkannya. Kemudian malaikat itu memberikan nasehat agar orang Cipai itu dapat melaksanakan arakarakan tersebut seperti yang dilihatnya, dan arak-arakan itulah kini yang disebut dengan tabuik"(Wawancara: 2012).
}

Mitos ini dimulai dari kematian Husain oleh pasukan Yazid bin Muawiyah, kemudian mayat Husain dan para pengikutnya dikuburkan di Karbala. Akan tetapi, masyarakat Pariaman membuat rekayasa sendiri yang bersifat imajinatif, dengan datangnya arak-arakan para malaikat beserta buraq pembawa jenazah Husain terbang ke langit, 
yang tidak bisa dihubungkan dengan fakta. Namun ketika membuat tabuik, mereka mampu mewujudkan arak-arakan malaikat dengan buraq dalam mitos itu, seperti upacara Tabuik yang ada sekarang.

Berbeda pula dengan tabot Bengkulu, mitosnya juga berawal dari tragedi Karbala. Berdasarkan catatan yang dibuat oleh penguasa Belanda di Bengkulu pada akhir abad ke-19, mitos tabot dilukiskan sebagai berikut.

\footnotetext{
"Mayat Husain yang tanpa kepala ditinggalkan di padang Karbala. Seseorang yang bernama Natsal, pembantu Husain mengetahui bahwa di dalam ikat pinggang $\mathrm{Hu}^{-}$ sain tersimpan sebuah intan atau jimat yang berharga. Menurut Natsal lebih baik ia mengambil barang itu, dari pada diambil atau dirampas oleh orang lain. Ketika Natsal membuka pakaian Husain untuk mengambil barang itu, kedua tangan Husain bergerak-gerak menolak tangan Natsal. Natsal kemudian menebas tangan mayat Husain, akan tetapi pada saat yang sama ia mendengar guruh, kilat menyambar ke segala arah dengan suara yang menakutkan. Melihat kejadian itu Natsal berbaring di tanah. Dalam keadaan sadar Natsal melihat bagaikan dalam mimpi sebuah istana raja berbentuk piramida muncul di sepanjang tempat itu, disertai lantunan irama-irama yang harmonis. Kemudian ia mendengar kata-kata; berilah jalan Nabi Adam, Nabi Ibrahim, Nabi Musa, Nabi Isa, Siti Fatimah, dan Nabi Muhammad memberikan penghormatan kepada Husain. Natsal melihat wajah Nabi Muhammad, lalu Nabi menampar wajah Natsal dengan mengucapkan kata-kata, untuk memberikan tanda perbuatan burukmu bukan hanya wajahmu yang tetap hitam, tetapi keturunanmu akan dilahirkan dengan wajah hitam.

Setelah kejadian itu, Natsal menyesali perbuatannya, ia pergi ke Mekkah memohon ampunan dari Allah di Ka'bah atas perbuatan buruknya itu. Pada saat ia berdoa Ja'far Ibnu Muhammad Siddik seorang ulama yang sedang mengelilingi Kabah, menemuinya dan menanyakan masalah apa yang dihadapi oleh Natsal. Natsal menjelaskan semua kejadian yang ia alami, lalu Ja'far memberikan jawaban kepadanya, bahwa dosa Natsal bisa diampuni dengan syarat ia dan keturunannya setiap tahun harus mengenang dan memperingati kematian Husain melalui suatu upacara yang khidmat" (Helfrich et al., 1888:192-193).
}

Natsal yang disebut sebagai pembantu Husain hanyalah sebuah rekayasa saja, begitu juga mimpinya. Akan tetapi, nama Natsal sangat dihormati oleh orang-orang Cipai Bengkulu termasuk para serdadu Cipai. Mereka menganggap Natsal sebagai leluhurnya, sehingga menjadi kewajiban bagi mereka melaksanakan upacara tabot secara khidmat setiap tanggal 1-10 $\mathrm{Mu}-$ haram setiap tahun, untuk menebus dosadosa Natsal. Mengenai bentuk tabot, pada awalnya keturunan Natsal membuat seperti menara yang memiliki unsur piramida, sebagai hasil penafsiran mereka terhadap mimpi Natsal di Karbala (Helfrich et al., 1888: 193). Akan tetapi, saat ini berbagai bentuk kreasi tabot sudah muncul, sebagai bentuk pengembangan oleh para pembuat tabot di Bengkulu. Ada kecenderungan yang mirip dengan menara masjid. Berdasarkan mitos itu, tabot di Bengkulu tidak memiliki buraq, meskipun dalam perkembangan sekarang sudah ada pula tabot yang memakai buraq (Haque, 2009: 22).

\section{Upacara Tabuik dan Tabot}

Upacara Tabuik dan Tabot sama-sama dilaksanakan pada awal hingga paroh pertama (1-10) Muharam dalam kalender tahun Hijriyah. Namun terjadi sedikit perbedaan, di Bengkulu upacara Tabot masih tetap dilaksanakan dari tanggal 1-10 Muharam, sementara di Pariaman sudah terjadi pergeseran waktu pelaksanaan dengan tidak lagi berpatokan pada tanggal 1-10 Muharam, tetapi bisa menjadi dari tanggal 1-11,12,13, dan 14 Muharam, dengan perhitungan hari puncak upacara bertepatan pada hari minggu. Pergeseran ini agaknya ingin mengadopsi dua kepentingan yakni, kepentingan penyelenggara (pemerintah, tokoh masyarakat, dan pemilik tabuik) dan kepentingan masyarakat penikmat. 


\section{Upacara Tabuik}

Upacara Tabuik termasuk upacara yang berdimensi keras dan bersifat kolosal. Pelaku utama upacara itu terdiri atas dua tabuik, yaitu tabuik pasa dengan pusat aktivitasnya di Kampung Perak, Pasir, dan pasar Pariaman (nagari Pasar Pariaman), dan tabuik subarang dengan pusat aktivitasnya di Kampung Pondok, Kampung Jawa, Kampung Cina, dan Jawi-Jawi (nagari Lima Koto Air Pampan). Kedua tabuik ini menggambarkan dua kelompok yang sedang berseteru, yang dianalogikan dengan pasukan Husain dan pasukan Yazid yang sedang berperang di Karbala. Walaupun sesungguhnya masing-masing pendukung tabuik itu sama-sama 'mengagungkan' dan merayakan peringatan kematian Husain, dan tidak satu pun yang berperan sebagai pasukan Yazid. Akan tetapi antara satu dengan lainnya saling tuding menjadi lawannya. Ini memang aktivitas budaya yang direkayasa untuk itu.

Bentuk-bentuk kekerasan itu muncul, seperti mengadu tabuik dan perkelahian antara kedua belah pihak. Perkelahian itu dianggap sebagai bagian penting dari upacara. Perkelahian merupakan luapan dan puncak atau klimaks dari konflikkonflik yang ada selama upacara. Tanpa

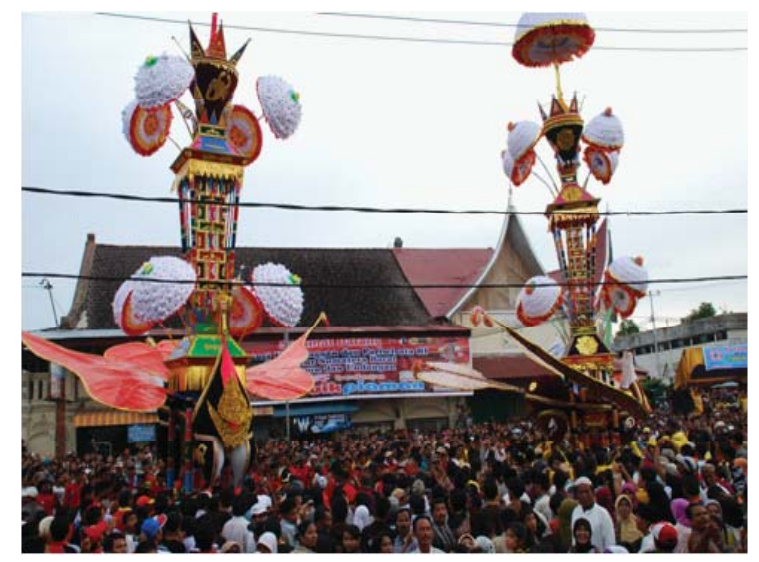

Gambar 1

Tabuik dihoyak pada upacara puncak dari siang sampai sore hari. (foto: Studio Alamsyah) ada perkelahian maka upacara dianggap 'dingin', karena bagian ini merupakan salah satu daya tarik pengunjung dan para perantau Pariaman untuk menyaksikan upacara Tabuik. Bagi para pengunjung jika tidak melihat bagian upacara yang menyajikan permainan keras, dianggap belum menyaksikan upacara Tabuik. Bagi mereka yang mengerti dengan upacara Tabuik, dalam kerangka fantasi fikirannya sudah terpola akan menyaksikan perkelahian dan bentuk permainan keras lainnya. Perkelahian itu bisa terjadi dua kali, yaitu pada upacara maambiak batang pisang dan maarak jari-jari atau maarak sorban.

Pada masa lalu korban-korban perkelahian dalam upacara Tabuik tidak merasa dendam dengan kejadian itu, walaupun mereka tahu orang yang mencederainya. Mereka menerima dengan keikhlasan dan dianggap sebagai pengorbanan, yang belum seberapa beratnya jika dibandingkan dengan pengorbanan Husain. Mereka yang berjiwa seperti itu memiliki pemahaman dan penghayatan yang dalam terhadap upacara yang dilakukan. Selain itu, para ninik mamak ${ }^{2}$ dan tokoh masyarakat dapat meredam dan merangkul kedua belah pihak untuk berdamai, serta memberikan pengertian tentang insiden yang terjadi sebagai bagian dari upacara Tabuik.

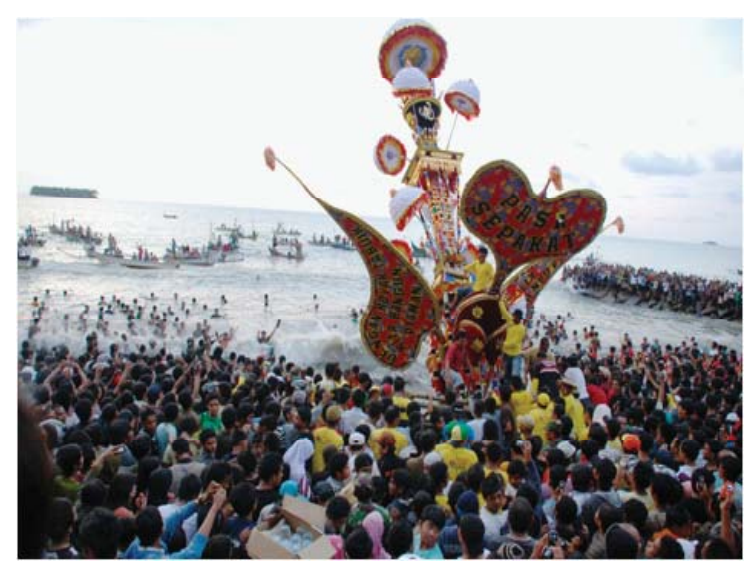

Gambar 2

Hari terakhir upacara, Tabuik dibuang ke laut. (foto: Studio Alamsyah) 
Upacara Tabuik yang bersifat kolosal terutama sekali dapat dilihat pada saat tabuikdihoyak dan tabuik dibuang ke laut. Kedua upacara itu dilaksanakan pada hari yang sama. Para pengunjung yang sekaligus berperan sebagai'pelayat' datang dari berbagai pelosok daerah menyaksikan upacara. Selama upacara berlangsung, diperkirakan jumlah pengunjung mencapai sekitar 200-an ribu orang. Mereka memadati areal wisata Pariaman seperti, Pantai Gandoriah, stasiun kereta api, areal sekitar pasar Pariaman.

Ritus-ritus yang terdapat dalam upacara Tabuik berdasarkan catatan Asril (2002: 66-67) adalah sebagai berikut:

“(1) Upacara maambiak tanah (mengambil tanah) merupakan prosesi ritual mengambil tanah ke sungai yang menggambarkan pengambilan mayat $\mathrm{Hu}-$ sain yang masih tertinggal di Karbala. Upacara ini dilaksanakan pada tanggal 01 Muharam pada sore hari selesai salat 'Ashar; (2) Upacara maambiak batang pisang merupakan prosesi ritual mengambil dan menebang batang pisang. Upacara ini menggambarkan ketajaman pedang Husain menebas lawan, tetapi ada juga yang menafsirkan sebaliknya saat-saat Husain dipancung oleh tentara Yazid.Upacara ini dilaksanakan pada tanggal 05 Muharam mulai dari sore hingga sekitar pukul 21.00. Puncak upacara terjadi perkelahian antara kedua pendukung tabuik. Pemicu perkelahian di antaranya adalah ansambel musik perkusi gandang tasa dengan ritme-ritme cepat, menghentak, dan suara keras; (3) Upacara maradai merupakan prosesi yang bertujuan mengundang simpati masyarakat guna menyumbang dana atau apa saja untuk membantu biaya pembuatan tabuik. Upacara ini dilakukan pada tanggal 06 Muharam (dapat menyesuaikan dengan rentang waktu upacara) pada malam hari sekitar pukul 19.30; (4) Upacara maatamatau mahatam merupakan penurunan jarijari dari rumah tabuik (keluarga tabuik), kemudian dibawa mengitari 'makam' atau imitasi kuburan Husain dalam da$r a g a^{3}$. Upacara ini menggambarkan jarijari Husain yang berserakan di Karbala, selanjutnya dikumpulkan di suatu tempat. Upacara ini dilaksanakan sekitar pukul 12.00-14.00; (5) Upacara maarak jari-jari adalah upacara berupa prosesi mengarak jari-jari dengan melintasi berbagai kampung sebagai gambaran keganasan tentara Yazid.Upacara ini dilakukan pada malam hari setelah upacara mahatam; (6) Upacara maaraksorban merupakan prosesi mengarak sorban (penutup kepala) sebagai gambaran setelah menemukan sorban $\mathrm{Hu}-$ sain. Upacara ini dilaksanakan dua hari menjelang upacara puncak, pada malam hari (pukul 20.00 - 22.00); (7) Upacara tabuik naiak pangkek adalah kegiatan penggabungan pangkek ${ }^{4}$ bawah dengan pangkek atas badan tabuik yang sebelumnya dibuat secara terpisah. Upacara ini dilaksanakan pada pagi hari (sejak subuh sampai pukul 09.00) pada hari puncak upacara; (8) Upacara maoyak tabuik merupakan upacara puncak dari seluruh rangkaian upacara Tabuik. Upacara ini dimulai dari pukul 11.00-16.00. Dua tabuik gadang (tabuik besar) dihoyak di jalan utama antara Simpang Tugu Tabuik hingga ke pasar Pariaman. Masing-masing pendukung akan mengoyak dan mengusung tabuik, bahkan membawa berlari ke arah tabuik lain untuk membangun suasana menjadi panas, meriah, dan atraktif; (9) Upacara mambuang tabuik merupakan upacara terakhir berupa prosesi membuang tabuik ke laut, sebagai gambaran mengantarkan jenazah Husain ke pemakaman. Upacara ini dilaksanakan dari pukul 16.00-18.30.

\section{Upacara Tabot}

Pelaksanaan upacara Tabot di Bengkulu terdiri atas dua kelompok tabot yaitu kelompok tabot imam dan kelompok tabot bangsal. Kedua kelompok tabot itu disebut tabot sakral. Masing-masing kelompok tabot memiliki pula anggota tabot pendukungnya, sehingga jumlah tabot yang digunakan dalam setiap upacara bisa mencapai 12 buah (Hamidy, 1991/1992:13-14), bahkan bisa lebih. Selain tabot sakral, juga diikuti oleh tabot pembangunan untuk menyemarakkan upacara Tabot, khususnya sejak upacara ini dimasukkan sebagai bagian dari pariwisata kota Bengkulu.

Adapun ritus-ritus yang terdapat dalam Upacara Tabot menurut Hamidy (1991/1992: 66-73) sebagai berikut: 
“(1) Mengambik tanah (mengambil tanah). Tanah yang diambil adalah tanah yang dianggap mengandung nilai magis; (2) Duduk penja (jari-jari). Penja adalah benda berbentuk telapak tangan manusia lengkap dengan jari-jarinya. Penja disebut juga dengan jari-jari. Penja menurut keluarga Sipai adalah benda keramat yang mengandung magis, maka harus dicuci dengan air bunga dan air limau [jeruk] setiap tahunnya. Setelah dicuci penja diletakkan di gerga ${ }^{5}$; (3) Menjara artinya mengandun atau saling berkunjung mendatangi kelompok tabot lain untuk beruji dol (bertanding membunyikan musik perkusi dol); (4) Meradai, berjalan mengitari kampung dilakukan oleh anak-anak usia 10-12 tahun dalam rangka pengumpulan dana untuk pembuatan tabot. Peserta meradai disebut jola. Meradai dilaksanakan pada tanggal 06 Muharam dari pagi sampai sore; (5) Arak penja: atau disebut juga arak jari-jari dilaksanakan pada tanggal 08 Muharam mulai pukul 19.0021.00 dengan menempuh rute yang telah ditentukan. Acara dimulai di lapangan Merdeka Bengkulu (lapangan Tugu Provinsi) dan selesai kembali di lapangan Tugu Peovinsi. Pelaku upacara adalah anak-anak dan remaja; (6) Arak serban: dilakukan pada tanggal 09 Muharam pada malam hari dari pukul 19.00-21.00. Arak serban berupa prosesi membawa serban (sorban) putih yang diletakkan pada tabot coki (tabot kecil), dilengkapi dengan bendera atau panjipanji berwarna putih, hijau atau biru yang bertuliskan "Hasan dan Husen" dengan kaligrafi Arab; (7) Gam: yaitu masa tenang yang ditentukan tidak boleh ada kegiatan apapun yang berkaitan dengan tabot. Gam dimulai dari pukul 07.00-16.00; (8) Arak gedang: yaitu prosesi kelompok tabot yang dimulai dari markas masing-masing menuju lapangan Merdeka. Menyatunya kelompokkelompok tabot dalam satu arak-arakan ini disebut dengan arak gedang (pawai akbar).Di lapangan Merdeka, tabot-tabot itu dibariskan seperti bershaf, sehingga disebut pula dengan tabot besanding (tabot bersanding). Upacara dimulai pada pukul 19.00-21.00. Selama upacara tabot besanding berbagai hiburan dan kesenian rakyat ditampilkan untuk menghibur para pengunjung; (9) Tabot tebuang: upacara tabot tebuang dimulai dari lapangan Merdeka, sekitar pukul 11.00 arak-arakan tabot menuju Padang Jati dan berakhir di kompleks pemakaman umum, Karabela. Di lokasi ini dimakamkan Imam Senggolo, pelopor upacara tabot. Upacara tabot tebuang dipimpin oleh dukun tabot dan dipandang bernilai magis.Selesai ritual tabot tebuang, tabot-tabot itu dibuang di sekitar makam".

Di Bengkulu, hampir semua ritus upacara yang dilakukan menggunakan sesajen, berupa makanan, minuman, dan berbagai kembang dan limau (jeruk). Cara ini menampakkan bahwa di Bengkulu nilai ritual dan sakral masih dipertahankan, meskipun gerusan perubahan ke arah penipisan nilai sakral tetap saja terjadi.

Merujuk pada mitos sebagai rujukan pembangun upacara Tabot di Bengkulu, tampak pada tahap-tahap upacara tidak menyajikan upacara yang berdimensi keras yang mengarah ke perkelahian seperti yang terjadi pada upacara Tabuik. Upacara yang dianggap keras dalam upacara Tabot adalah upacara menjara (beruji dol). Inti dari upacara menjara adalah beruji dol (pertandingan $\left.d o l^{6}\right)$; masing-masing kelompok tabot berusaha mengalahkan kelompok lain. Kelompok yang paling terampil memainkan dol (dol dan tasa) dan paling sedikit dol pecah (robek membrannya) dianggap menang (Hamidy, 1991: 89-90). Kekerasan ditunjukkan dengan melampiaskan emosional pendukung upacara melalui pemain musik

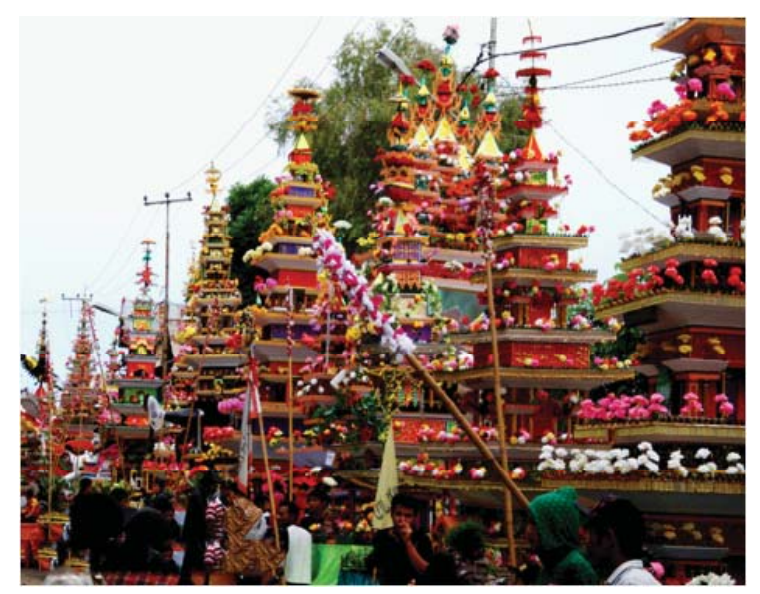

Gambar3

Arak-arakan tabot pada puncak upacara 10 Muharam

(Foto: Nuruliman Supardi

http://www.bengkulu-online.com, diunduh 12 Des 2011) 
ke alat musik dol. Mereka secara fisik tidak melakukan persentuhan antar kelompok pendukung tabot, apalagi perkelahian.

Berujidol dilakukan di lapangan terbuka, sehingga dapat disaksikan oleh banyak orang.Bahkan Berujidol dianggap salah satu bagian upacara yang mampu menarik perhatian banyak penonton. Berujidol dilakukan di dua tempat yaitu, di kelompok tabot imam dan di kelompok tabot bangsal. Mereka saling mengunjungi secara bergantian selama dua malam. Lagu-lagu yang biasa dimainkan dalam beruji dol adalah Matammatam, Suwena, dan Suweri. Ketiga lagu ini sama-sama dimainkan dalam waktu yang bersamaan. Lagu Suweri merupakan lagu andalan bagi setiap kelompok tabot. Masyarakat sangat mengetahui bahwa lagu tersebut sangat disukai. Para pemusik biasanya memainkan lagu ini dengan penuh semangat hingga bermain dengan tenaga yang maksimal. Akibatnya sering terjadi kerusakan pada alat musik seperti pada kulit (membrane) robek, pemukul (stick) patah, resonator instrumen retak, dan lainlain (Hanefi, et al., 1998: 45).

Situasi ini sangat berbeda dengan upacara Tabuik di Pariaman. Gandang tasa sebagai musik pendukung upacara justru digunakan untuk membangun semangat "heroik" dan "patriotik" di antara kedua kelompok tabuik. Lagu-lagu Oyak Tabuik dan Sosoh sebagai lagu utama, dimanfaatkan untuk membangun emosional para pendukung tabuik, khususnya untuk membangun emosi ke arah perkelahian dan yang berdimensi keras (Muchtar, 2005:70-71).

\section{Perubahan dan Perkembangan Upacara}

Perubahan dan perkembangan yang terjadi pada upacara Tabuik dan upacara Tabot berbeda bentuk dan jenisnya. Ada yang berubah dari aspek nilai ritual dan sakralnya, dan ada pula yang berkembang secara parsial dari aspek musiknya saja. Di Bengkulu upacara berkembang secara parsial, yakni dari aspek musiknya. Pada masa lalu, dol adalah bagian yang tidak bisa dipisahkan dari upacara Tabot. Dol hanya dapat dimainkan bersamaan dengan upacara Tabot, sebagai musik pendukung upacara.Akan tetapi, pada tahun 1980-an dan 1990-an dol sudah dapat ditampilkan secara terpisah untuk penyambutan tamu pemerintah, meskipun masih dalam bentuk ansambel yang aslinya. Perkembangan yang cukup menggembirakan adalah ketika dol dijadikan sebagai sumber penataan musik kreasi untuk iringan tari "baru" (kreasi) dan untuk musik kreasi.

Dalam penelitian Haque (2009: 46-51), ada tiga aspek perkembangan yang terjadi pada dol, yaitu: dol sebagai media seremonial di kota Bengkulu; dol dijadikan sebagai materi pembelajaran musik di sekolah dan di sanggar; dol sebagai sumber garapan komposisi baru. Dol sebagai media seremonial disajikan pada acara penyambutan tamu-tamu penting, acara ulang kota Bengkulu, acara yang bersifat umum lainnya, dan penggabungan dol dengan musik tradisi lainnya seperti gendang sarunai dan gamat yang digunakan untuk hiburan. Dol sebagai materi pembelajaran di sekolah, walaupun masih bersifat ekstrakurikuler, tetapi telah diajarkan di sekolah menengah pertama dan sekolah menengah atas di berbagai daerah, khususnya di kota Bengkulu.

Perkembangan yang cukup menarik adalah dol dijadikan sebagai sumber penciptaan karya baru. Dol telah digabung dengan berbagai alat musik di luar tradisinya. Misalnya dengan menghadirkan gitar bass elektrik, kolintang, set rebana, dan cara memainkan dol pun lebih atraktif. Misalnya, dol tidak saja diletakkan di lantai, tetapi telah disandang dan dimainkan sambil berbuai atau berayun, bahkan sambil tidur. Pertunjukan ini pun kemudian disebut dengan dol babuai (Haque, 2009: 58). Yang tak 
kalah menarik juga perkembangan yang terjadi dari aspek alat musiknya, berbagai jenis ukuran dol pun dibuat untuk keperluan perbedaan atau variasi warna bunyi. Para remaja Bengkulu sangat antusias memainkan dol kreasi ini.

Di Pariaman perubahan yang terjadi adalah pada nilai sakral upacara dan juga dalam bentuk parsial. Upacara Tabuik tidak lagi dilaksanakan dari tanggal 1-10 Muharam, melainkan berubah menjadi tanggal 1-11, 12, 13, dan 14 Muharam, yang diperlukan upacara puncak maoyak tabuik bertepatan pada hari minggu. Perubahan ini berorientasi pada pariwisata. Artinya, jika upacara puncak dilakukan pada hari minggu maka akan banyak orang yang menyaksikannya. Imbas dari itu, ekonomi masyarakat juga terangkat, mulai dari penjual makanan, transportasi, pengelola parkir, hingga penginapan. Namun demikian, cara praktis ini ternyata telah mengaburkan nilai-nilai sakral kesejarahan peristiwa Karbala sebagai titik tolak upacara. Oleh karena,pada tanggal 10 Muharam 680 (61 H) adalah hari kematian Husain di Karbala. Lambat laun generasi berikutnya tidak akan tahu lagi makna 10 Muharam dalam upacara Tabuik.

Bentuk lain dari pengembangan upacara Tabuik adalahperayaan Hoyak Tabuik yaitu cuplikan dari salah satu rangkaian upacara Tabuik. Biasanya yang diambil adalah upacara puncak, maoyak tabuik. Pelaksanaannya menurut Asril (2008:74) sudah terlepas dari semua aspek ritual dan sakral, seperti:

“(1) Pelaksanaannya tidak diharuskan pada bulan Muharam (tergantung hajatan); (2) Tidak mengikuti kronologi/urutan ritus-ritus upacara Tabuik;(3) Dilaksanakan di luar kota Pariaman (seperti: Padang, Pekan Baru, Batam, Jakarta, Padangpanjang, Bukittinggi, Batu Sangkar, Payakumbuh, Darmasraya); (4) Tidak diperlukan bendabenda sakral; (5) Tidak diharuskan pelaksananya masyarakat dari nagari Pasar Pariaman dan V Koto Air Pampan-pelaksana masyarakat Pariaman di perantauan; (6) Tabuik yang diusung tidak harus dua buah, dibolehkan satu saja; (7) Ukuran tabuik yang diusung pun relatif, tidak harus sama tingginya dengan tabuik gadangyang digunakan di kota Pariaman; (8) Setelah perayaan selesai, tabuik tidak harus dibuang".

Semua pelaksanaan perayaan Hoyak Tabuik dengan ketentuan tersebut, disebabkan karena tujuan dan makna perayaannya tidak terkait lagi dengan peringatan kematian Husain. Perayaan ditujukan untuk memeriahkan suatu event, baik yang dilaksanakan oleh pemerintah daerah maupun yang dilakukan sendiri oleh masyarakat Pariaman di perantauan.

\section{PENUTUP}

Secara kultural, upacara Tabuik dan upacara Tabot merupakan peninggalan ritual utama keagamaan Islam Syi'ah di pantai barat Sumatra. Akan tetapi, secara teologis paham keagamaan Syi'ah sangat sulit dilacak, khususnya di Pariaman, Sumatra Barat. Upacara Tabuik dan upacara Tabot meskipun berasal dari peristiwa yang sama (perang Karbala), tetapi dalam implementasinya sangat banyak dipengaruhi oleh interpretasi masyakarat dengan cara "pemitosan" sejarah yang kemudian seolah-olah seperti legenda. Unsur-unsur budaya lokal dan kebiasaan masyarakat juga turut mempengaruhi artefak tabuik dan tabot, bentuk upacara, spirit, dan pelaksanaannya. Bagian yang tak terelakkan juga adalah perubahan yang terjadi pada kedua upacara tersebut bisa terjadi secara parsial dan penggerusan nilai sakral.

\section{Catatan Akhir}

${ }^{1}$ Imam oleh kebanyakan para penganut Syi'ah, dianggap memperoleh ilham ilahi dan terjaga dari dosa dan khilaf. Imam adalah orang yang bisa diharapkan membawa komunitas 
dangan selamat melewati suatu krisis, oleh sebab itulah pada masa-masa sulit orang memerlukan imam. Periksa, W. Montgomery Watt, Kejayaan Islam Kajian Kritis dari Tokoh Orientalis, terj. Hartono Hadikusumo, (Yogyakarta: Tiara Wacana, 1990).

${ }^{2}$ Ninik mamak adalah para pemimpin suku atau kaum dalam tatanan masyarakat adat Minangkabau.

${ }^{3}$ daraga adalah areal yang dimitoskan dan disucikan sebagai tempat makam (kuburan) Husain.

${ }^{4}$ Dalam pembuatan tabuik Pariaman dilakukan atas dua bagian, yaitu bagian atas dan bagian bawah. Setiap bagian disebut dengan pangkek. Pangkek bawah adalah kaki tabuik dan burak, sedangkan pangkek ateh (atas) terdiri atas bungo salapan, gomaik, puncak tabuik, biliak-biliak, dan lain sebagainya.

${ }^{6}$ gerga adalah salah satu tempat kegiatan tabot 'disucikan'.

${ }^{7}$ dol sejenis gendang bermuka satu berbentuk kettle drum, dengan ukuran diameter cukup besar antara 50-60 cm. Dol dimainkan sambil berdiri dengan cara diletakkan di lantai atau tanah.

\section{Daftar Pustaka}

Asril Muchtar

2002 'Pertunjukan Gandang Tambua dalam Upacara Ritual Tabuik di Pariaman Sumatra Barat', Tesis S2 UGM Yogyakarta.

2008 'Upacara Tabuik dalam Dimensi Sosial Budaya Masyarakat Pariaman: Keberlangsungan dan Perubahannya' Manuskrip. Padangpanjang: STSI.

Azyumardi Azra

2000 'Syiah di Indonesia: Antara Mitos dan Realitas' (pengantar) dalam A. Rahman Zainuddin dan M. Hamdan Basyar ed. Syiah dan Politik di Indonesia: Sebuah Penelitian. Bandung: Mizan dan PPW-LIPI.

Badri Yatim

2000 Sejarah Peradaban Islam: Dirasah Is lamiyah II. Jakarta: Raja Grafindo Persada.

Badrul Munir Hamidy, ed.

1991/ Upacara Tradisional Daerah Beng1992 kulu: Upacara Tabot di Kotamadya Bengkulu. Jakarta: Direktorat Sejajarah dan Nilai Tradisional Depdikbud.

Brockelmann, Carl.

1956 History of the Islamic People. London Routledge dan Kegan Paul Ltd

Departemen Agama RI

2006 Al-Quran Tajwid dan Terjemahannya. Bandung: Syaamil Cipta Media.

Gibb, H.A.R dan J.H. Kamer ed.

1974 Shorter Encyclopaedia of Islam. Leiden: EJ Brill.

Grunebaum, G.E. von

1951 Muhammad dan Festival. New York: Henry Schuman, Inc.

Hanefi, et al.

1998 'Musik Tabot dalam Beruji Dol di Bengkulu: Tinjauan Musikologis' Laporan Penelitian. Padangpanjang: ASKI.

Helfrich, O. L. et al.

1888 'Het Hasan-Hosein of Taboet-Feest te Benkoelen', dalam Internationales Archiv fur Ethnographie. Leiden: Verlag von P. W. M. Trap.

Kartomi, Margaret J.

1986 'Tabut - a Shiah Ritual Tranplanted from India to Sumatra', dalam David P. Chandler dan M.C. Ricklefs (ed.) Nineteenth and Twentieth Century Indonesia. Clayton: Centre of Southeast Asia Studies, Monash University. 
Kementerian Agama RI

2010 Al-Quranulkariim Terj. Tafsir Perkata Bandung: CV Insan Kamil.

Ronkel, Ph. S. van.

1914 'Nadere gegevens omtrent het Hasan-Hoesain feest', dalam Tijdschrift voor Indische Taal--,Land--, en Volkenkunde. Batavia: Albrecht \& Co.

Tamim Ansary

2009 Destiny Disrupted: A History of the World through Islamic Eyes (Dari Puncak Bagdad: Sejarah Dunia Versi Islam). Terj. Yuliani Liputo. Jakarta: Zaman.

Umar Faruk Assegaf

2010 'Madhhab Ahl Al-Bayt in Nusantara the Past and Present', dalam Jurnal Al-Qurba jurnal Peradaban dan Kebudayaan Islam, Vol.1, no. 1 November.

Yudhi Andoni

2010 'Kesalehan nan Terlampauhi: Desakralisasi Ritus Hoyak Hosen di
Pariaman Sumatra Barat', dalam Al-Qurba jurnal Peradaban dan Kebudayaan Islam, Vol. 1, No. 1 November.

Yulimarni

2011 'Tabut Subarang Tahun 2010 dalam Tradisi Muharam Masyarakat Pariaman di Sumatra Barat', Tesis, Program Pascasarjana Penciptaan dan Pengkajian Seni, Institut Seni Indonesia Yogyakarta.

Zubaedi

2008 'Revitalisasi Tabot Untuk Membangun Kerukunan Umat Beragama di Bengkulu', dalam Harmoni Jurnal Multikultural dan Religius, Vol. VII, No. 27, Juli-September.

Webtografi:

Nuruliman Suparlan

2011 'Arak-arakan Tabot'. http://www. bengkulu-online.com. Diunduh tanggal 29 Desember 2011. 